\title{
Tuberculosis infection in children with proteinuria/nephrotic syndrome
}

\author{
HANNA SZYMANIK-GRZELAK', ELŻBIETA KUŹMA-MROCZKOWSKA ${ }^{l}$, PIOTR SKRZYPCZYK', \\ TERESA BIELECKA ${ }^{2}$, IWONA KOTULA ${ }^{3}$, MAEGORZATA PANCZYK-TOMASZEWSKA ${ }^{l}$
}

${ }^{1}$ Department of Pediatrics and Nephrology, Medical University of Warsaw, Poland

${ }^{2}$ Department of Pediatric Pulmonology and Allergology, Medical University of Warsaw, Poland

${ }^{3}$ Department of Laboratory Diagnostics and Clinical Immunology of Developmental Age, Medical University of Warsaw, Poland

\begin{abstract}
Children with nephrotic syndrome (NS) are at greater risk of infections than the general population, due to immunodeficiency in the course of the disease and the treatment. In this study we present 4 children (2 girls, 2 boys), mean age $7.6 \pm 5.1$ years, with NS/proteinuria and latent tuberculosis in 3 children and lymph node tuberculosis in 1 child. The reasons for testing these children for tuberculosis $(T B)$ were the evaluation of the epidemiological status before treatment with corticosteroids (GCS), leukopenia and the relapse of NS, and non-nephrotic proteinuria. The diagnosis of TB infection was based on positive IGRA (Interferon-Gamma Release Assay). Chest X-ray was normal in all the children. Chest CT scan revealed an enlargement of lymph nodes in 1 child. The children were treated with isoniazid (3 children) and isoniazid, rifampicin and pyrazinamide (1 child). Three children with idiopathic nephrotic syndrome were treated with prednisone. The child with non-nephrotic proteinuria was treated with enalapril. Proteinuria disappeared in all children during anti-TB treatment.
\end{abstract}

Key words: children, tuberculosis, proteinuria, nephrotic syndrome.

(Cent Eur J Immunol 2017; 42 (3): 318-323)

\section{Introduction}

Tuberculosis, an infectious disease caused by Mycobacterium tuberculosis complex (among others M. tuberculosis, M. bovis, $M$. africanum), continues to be an epidemiological problem in the $21^{\text {st }}$ century [1]. The highest incidence of tuberculosis (TB), above 500/100,000, is observed in Africa, the lowest $(<10 / 100,000)$ in Western Europe, Canada, United States, Australia and New Zealand $[1,2]$. In Poland, the incidence rate of TB is 16.8/100,000 [3]. As regards children $<14$ years, 62-116 cases have been reported annually over the last 5 years; with the incidence rate being 1.1-2/100,000 in this group [3, 4]. Latent tuberculosis infection (LTBI) is defined as a state of persistent immune response to prior-acquired Mycobacterium tuberculosis antigens without evidence of clinically manifested active TB [5]. Approximately $10 \%$ of people with LTBI will develop active TB disease in their lifetime, with the majority developing it within the first five years after initial infection. However, the risk of developing TB disease following infection depends on several factors, the most important one being the immunological status of the host [5].

Diagnostic tests for TB infection in children include: tuberculin test (TT) and interferon $\gamma($ IFN- $\gamma$ ) realease assay (IGRA). Active TB infection is recognized on basis of bacteriological, radiological and invasive examinations (bronchoscopy or biopsy of an organ suspected of tuberculous lesions) [4-9]. According to the American Academy of Pediatrics (AAP) [6] and the guidelines of the Polish Respiratory Society (Polskie Towarzystwo Chorób PtucPTChP) [7], it is recommended to use IGRA tests in the diagnosis of LTBI in immunocompetent adults and in children over 5 years of age.

IGRA are based on measurement of the level of secreted IFN- $\gamma$ (QuantiFERON-TB Gold (QFT) ELISA) [10] or measurement of the number of IFN-secreting cells (T-SPOT.TB test) after the incubation of the patient's whole blood with isolated mycobacterial antigens [11]. An increased synthesis of IFN- $\gamma$ indicates the presence of memory cells recognizing mycobacterial antigens in the patient's blood sample, which confirms TB infection [1013]. The major advantage of IGRA compared with TT is its significantly better specificity and lack of influence of BCG (Bacille Calmette-Guerin) vaccination on test results, which is of particular importance for vaccinated populations, including Polish one [7-9, 12-14]. In case of small children it is important to perform both TT and IGRA tests, keeping in mind that the blood for IGRA should be collected no later than on TT reading day [8].

Correspondence: Piotr Skrzypczyk, Department of Pediatrics and Nephrology, Medical University of Warsaw, Żwirki i Wigury 63A, 02-091 Warsaw, e-mail: pskrzyp@gmail.com

Submitted: 11.08.2017; Accepted: 17.10.2017 
Material for bacterial testing for M. tuberculosis infection may include body fluids (i.e. pleural exsudate, urine, bronchial lavage, gastric washing) and tissue material. BACTEC MGIT (mycobacterial growth indicator tube) system may be used to detect even a single mycobacterium in $1 \mathrm{~mL}$ of material; the results are available after 6 weeks $[5,8,9]$. Genetic tests, such as the M. tuberculosis Direct Test/Gen-Probe test (Amplified Mycobacterium Tuberculosis Direct Test), confirm the presence of $M$. tuberculosis genetic material (even one mycobacterial cell) within a few days $[8,9]$. Radiological chest examinations (X-ray or computed tomography) are primary tools in diagnostics of pulmonary tuberculosis. It should be emphasized that radiological tests may suggest the diagnosis of TB but final diagnosis cannot be stated solely on imaging studies. Bronchoscopy is used to evaluate the appearance of the tracheobronchial tree and to collect the bronchoalveolar lavage directly from the lower respiratory tract or to perform bronchial biopsy. Biopsy material is histologically and bacteriologically tested. The presence of granuloma in histopathological examination is typical but not pathognomonic for TB diagnosis, because granulomas may also be found in patients with sarcoidosis or granulomatous diseases [9].

Tuberculosis prevention involves BCG vaccination, prophylactic treatment of LTBI and the early detection and treatment of new cases of active tuberculosis. The $\mathrm{BCG}$ vaccine is a part of the mandatory immunization program in Poland and its effectiveness in protection against the most severe forms of TB infection has been clearly proven [15]. Three or four antituberculous agents (isoniazid, rifampicin, pyrazinamide, ethambutol or streptomycin) are used in the treatment of TB. The treatment of latent tuberculosis infection lasts 6 months and consists of daily administration of one antituberculous drug or 3 months when two antituberculous drugs are administered [1, 5-7].

Nephrotic syndrome (NS) is caused by the urinary loss of protein which exceeds the body's compensatory capacity. The diagnostic criteria of NS include urinary protein loss of $>50 \mathrm{mg} / \mathrm{kg} /$ day and serum albumin $\leq 25 \mathrm{~g} / \mathrm{l}$, hyperlipidemia and edema [16-20]. Increased urinary protein excretion in NS is due to an increased permeability of the glomerular filtration membrane caused by various pathological factors or defects in their microstructure. Primary NS is recognized when only symptoms of NS are present, without any symptoms of disease from other systems. In this group, idiopathic nephritic syndrome (INS) and primary glomerulonephritis are included. Secondary NS develops in the course of other diseases (systemic, infectious), after drug exposure, in poisonings. INS accounts for $90 \%$ of cases of NS in children between 1-10 years, and 50\% of cases of NS in children over 10 years [17]. The treatment of INS involves administration of prednisone at a dose of $60 \mathrm{mg} / \mathrm{m}^{2} /$ day or $2 \mathrm{mg} / \mathrm{kg} /$ day (max. $60 \mathrm{mg} /$ day) for 4 weeks followed by $40 \mathrm{mg} / \mathrm{m}^{2} / 48$ hours with a gradual tapering in consecutive weeks [19-21]. Relapses of INS in children are often preceded by respiratory tract infections. In these cases, increasing the frequency of prednisone administration from "every second day" (q2d) to "every day" (qd) for 5-7 days reduces the risk of NS recurrence [19-21].

The pathogenesis of INS includes the activity of an abnormal T-cell clone that produces factors damaging glomerular filtration membrane and thus increasing its albumin permeability. The synthesis of protein permeability factors may be the effect of stimulation of T-cell clones by B-lymphocytes under conditions of an impaired co-operation between these cells [22]. In children with primary NS, there may be a relationship with TB infection preceding the onset of NS [23]. It is also possible to develop TB disease during the treatment of NS with GCS and/or immunosuppressive medications $[5,7,24]$.

\section{Aim of the study}

The presentation of Mycobacterium tuberculosis infection in 4 children with NS or proteinuria diagnosed over the past 2 years in one center of pediatric nephrology.

\section{Material and methods}

In the years 2014-2016, 102 children with proteinuria/ NS hospitalized in our tertiary center of pediatric nephrology were tested withQuantiFERON-TB test. During this period 4 children with proteinuria/NS ( 2 girls, 2 boys), aged from 4 to 15 years (mean $7.6 \pm 5.1$ years), were diagnosed with tuberculosis infection.

Following clinical and biochemical data were analyzed in all 4 children with diagnosed TB infection: sex, age of diagnosis of TB infection, nephrological diagnosis and age of kidney disease onset, laboratory tests at the time of TB diagnosis: proteinuria [mg/dl], [mg/kg/24 h], urine sediment, peripheral blood morphology, C-reactive protein (CRP) [mg/dl], serum creatinine $[\mathrm{mg} / \mathrm{dl}]$, GFR according to revised Schwartz formula [25] [ml/min/1.73 $\left.\mathrm{m}^{2}\right]$, serum albumin [g/l], reason for performing and result of QuantiFERON-TB Gold (QFT®) ELISA test (Cellestin, QIAGEN Comp., Victoria, Australia), results of bronchoalveolar lavage and urine TB microbiological tests: bacterioscopy, Gen-Probe i.e. Amplified Mycobacterium Tuberculosis Direct Test (Hologic, Inc. San Diego, CA, USA), BACTEC MGIT 960 System (Beckton, Dickinson and Company, Franklin Lakes, NJ, USA), results of imaging studies (abdominal ultrasonography, chest radiogram, chest computed tomography), history of contact with known or suspected TB patient, pulmonological diagnosis, and finally nephrological and anti-TB treatment.

\section{Case reports}

The clinical, laboratory and treatment data of 4 patients with diagnosed TB infection are presented in Table 1. As 
Hanna Szymanik-Grzelak et al.

Table 1. The clinical, laboratory and treatment data of 4 patients with TB infection and proteinuria/nephrotic syndrome

\begin{tabular}{|c|c|c|c|c|}
\hline \multirow[t]{2}{*}{ Parameter } & \multicolumn{4}{|c|}{ Case No. } \\
\hline & 1 & 2 & 3 & 4 \\
\hline Sex & 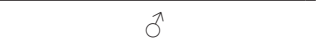 & $\hat{\sigma}$ & q & $\hat{\sigma}$ \\
\hline $\begin{array}{l}\text { Age of diagnosis of TB } \\
\text { infection (years) }\end{array}$ & 4.5 & 4 & 15 & 7 \\
\hline Nephrological diagnosis & $\begin{array}{l}\text { idiopathic } \\
\text { nephrotic syndrome - } \\
\text { first episode }\end{array}$ & $\begin{array}{c}\text { relapse of non-nephrotic } \\
\text { proteinuria } \\
\text { idiopathic } \\
\text { nephrotic syndrome } \\
\text { two relapses }\end{array}$ & $\begin{array}{c}\text { relapse of non- } \\
\text { nephrotic proteinuria } \\
\text { idiopathic } \\
\text { nephrotic syndrome } \\
\text { five relapses }\end{array}$ & $\begin{array}{l}\text { non-nephrotic } \\
\text { proteinuria } \\
\text { renal biopsy-mesangial } \\
\text { proliferation }(++)\end{array}$ \\
\hline $\begin{array}{l}\text { Age of kidney disease onset } \\
\text { (years) }\end{array}$ & 4.5 & 2 & 4 & 6 \\
\hline \multicolumn{5}{|l|}{ Laboratory tests: } \\
\hline $\begin{array}{l}\text { Proteinuria: } \mathrm{mg} / \mathrm{dl} \\
\mathrm{mg} / \mathrm{kg} / \mathrm{day}\end{array}$ & $\begin{array}{l}470 \\
88\end{array}$ & $\begin{array}{c}145 \\
8\end{array}$ & $\begin{array}{c}131 \\
58\end{array}$ & $\begin{array}{c}118 \\
37\end{array}$ \\
\hline $\begin{array}{l}\text { Erythrocyturia } \\
\text { (/high-power field) }\end{array}$ & 0 & 0 & 0 & $35-40$ \\
\hline $\begin{array}{l}\text { Leukocyturia } \\
\text { (/high-power field) }\end{array}$ & 0 & $0-1$ & $2-5$ & $0-1$ \\
\hline $\mathrm{Hb}(\mathrm{g} / \mathrm{dl})$ & 12.3 & 13.6 & 14.9 & 12.3 \\
\hline WBC (ths $/ \mathrm{mm}^{3}$ ) & 7.6 & 8.4 & 2.7 & 8.4 \\
\hline $\begin{array}{l}\text { Blood smear }(\%) \\
\text { neutrophils/lymphocytes }\end{array}$ & $39.3 / 48.4$ & $40.3 / 56.6$ & $44.5 / 44.2$ & $31.7 / 46.6$ \\
\hline CRP (mg/dl) & $<0.5$ & $<0.5$ & $<0.5$ & $<0.5$ \\
\hline Creatinine (mg/dl) & 0.3 & 0.4 & 0.7 & 0.4 \\
\hline $\begin{array}{l}\text { GFR ac. to Schwartz } \\
\text { formula }\left[\mathrm{ml} / \mathrm{min} / 1.73 \mathrm{~m}^{2}\right]\end{array}$ & 154.9 & 108.4 & 96.2 & 134.2 \\
\hline Albumin (g/l) & 23 & 36 & 24 & 39 \\
\hline $\begin{array}{l}\text { QuantiFERON (IU/ml) } \\
\text { (normal range }<0.35 \mathrm{IU} / \mathrm{ml} \text { ) }\end{array}$ & 4.69 & 1.107 & 0.492 & 8.95 \\
\hline $\begin{array}{l}\text { Reason for performing } \\
\text { QuantiFERON test }\end{array}$ & $\begin{array}{l}\text { evaluation of the } \\
\text { epidemiological status } \\
\text { before first treatment with } \\
\text { GCS, recurrent respiratory } \\
\text { symptoms }\end{array}$ & $\begin{array}{l}\text { evaluation of the } \\
\text { epidemiological status } \\
\text { before treatment with } \\
\text { GCS, recurrent respiratory } \\
\text { symptoms }\end{array}$ & $\begin{array}{l}\text { relapse of proteinuria, } \\
\text { leuthkopenia, recurrent } \\
\text { respiratory symptoms }\end{array}$ & $\begin{array}{l}\text { proteinuria, } \\
\text { erythrocyturia, recurrent } \\
\text { respiratory symptoms }\end{array}$ \\
\hline \multicolumn{5}{|l|}{ Bronchoalveolar lavage: } \\
\hline Bacterioscopy & not performed & negative & negative & not performed \\
\hline Gen-Probe & & negative & negative & \\
\hline BACTEC system & & negative & negative & \\
\hline \multicolumn{5}{|l|}{ Urine: } \\
\hline Bacterioscopy & not performed & not performed & negative & negative \\
\hline Gen-Probe & & & negative & negative \\
\hline BACTEC system & & & negative & negative \\
\hline US of urinary tract & normal & normal & normal & normal \\
\hline Chest X-ray & normal & normal & normal & normal \\
\hline
\end{tabular}


Table 1. Cont.

\begin{tabular}{|c|c|c|c|c|}
\hline \multirow[t]{2}{*}{ Parameter } & \multicolumn{4}{|c|}{ Case No. } \\
\hline & 1 & 2 & 3 & 4 \\
\hline CT scan & normal & $\begin{array}{l}\text { lymph node package at the } \\
\text { right side of the trachea } \\
30 \times 19 \times 16 \mathrm{~mm} \text { and single } \\
\text { perihilar and subcarinal } \\
\text { nodes up to } 8 \mathrm{~mm}\end{array}$ & not performed & normal \\
\hline $\begin{array}{l}\text { History of contact with } \\
\text { known or suspected TB }\end{array}$ & negative & negative & negative & $\begin{array}{l}\text { cousin IGRA (+), full } \\
\text { family data in progress }\end{array}$ \\
\hline Pulmonological diagnosis & LTBI & $\begin{array}{c}\text { intrathoracic lymph nodes } \\
\text { TB }\end{array}$ & LTBI & LTBI \\
\hline Treatment of NS/proteinuria & $\begin{array}{c}\text { prednisone } \\
60 \mathrm{mg} / \mathrm{m}^{2} / \text { day }= \\
46 \mathrm{mg} / \text { day }\end{array}$ & $\begin{array}{c}\text { prednisone } \\
30 \mathrm{mg} / \mathrm{m}^{2} / \text { day }= \\
24 \mathrm{mg} / \text { day }\end{array}$ & $\begin{array}{l}\text { prednisone } \\
60 \mathrm{mg} / \text { day }\end{array}$ & $\begin{array}{c}\text { enalapril } \\
2.5 \mathrm{mg} / \mathrm{day}\end{array}$ \\
\hline Treatment of TB & $\begin{array}{l}\text { isoniazid } \\
6 \text { months }\end{array}$ & $\begin{array}{l}\text { isoniazid }+ \text { rifampicin }+ \\
\text { pyrazinamide } 6 \text { months }\end{array}$ & $\begin{array}{l}\text { isoniazid } \\
6 \text { months }\end{array}$ & $\begin{array}{l}\text { isoniazid } \\
6 \text { months }\end{array}$ \\
\hline
\end{tabular}

for primary nephrologic disease, 3 children had idiopathic nephrotic syndrome. Half of the children had nephrotic range proteinuria at the moment of TB infection diagnosis. Abnormal urine sediment was revealed in one child. As for inflammatory markers, all children apart from one with leukopenia had normal white blood cell count and all the patients had CRP level within normal limits. Kidney function was normal in all 4 children. Two children had hypoalbuminemia. Positive result of QuantiFERON-TB test was found in all the patients. In 2 children (cases No. 2 and 3) bronchoalveolar lavage was performed and 3 children were tested with Gen-Probe and BACTEC MGIT system (cases No. 2, 3, 4). In none of the patients positive results of genetic tests, bacterioscopy or culture were found. Chest X-ray and ultrasonography of the urinary tract were performed in all these 4 children and revealed no abnormalities. Chest CT examination was performed in 3 children (cases No. 1, 2, 4). At the moment of diagnosis, 3 children were treated with GCS. Three patients were diagnosed with LTBI. One child (case No. 2) was diagnosed with lymph node TB after exclusion of other possible causes of lymphadenopathy (Mycoplasma pneumoniae, Chlamydophila pneumoniae, Toxoplasma gondii, and neoplasms). LTBI was treated with 6-month therapy with isoniazid. A triple therapy, including isoniazid, rifampicin, and pyrazinamide was used in a child with lymph node tuberculosis during GCS treatment. In the child with proteinuria and erythrocyturia (patient No. 4), chemoprophylaxis with isoniazid and renoprotective treatment with enalapril was used. Proteinuria subsided during antituberculous treatment and concomitant nephrological treatment in all the patients.

\section{Discussion}

Currently, Poland is one of the countries with a low incidence of tuberculosis (i.e. $<20 / 100,000 /$ year) [3]. TB most commonly affects lungs, but tuberculosis lesions may occur in various organs [1-6]. In 2016, extrapulmonary tuberculosis was diagnosed in $5.1 \%$ of patients with TB in Poland [3]. The location of TB in the urinary tract is considered to be the fourth most common location of the disease $[3,26]$. In most patients with renal tuberculosis the most common symptoms are sterile pyuria and/or microscopic erythrocyturia and dysuria; NS is rarely diagnosed $[23,26]$. Tuberculosis of the urinary tract in children is extremely uncommon; symptoms usually appear 5 to 15 years after infection [27].

In most cases, the human immune system is able to protect against the development of TB diesase. In only $5-10 \%$ of infected patients symptomatic TB develops, while in the remaining cases mycobacteria remain latent [5]. Latent tuberculosis infection, under favorable conditions, may undergo progression to active disease [5-7].

According to WHO recommendations, diagnostic tests for $M$. tuberculosis infection are indicated in the following clinical situations: 1) after contact with pulmonary tuberculosis, 2) prior to planned immunosuppressive therapy (including the preparation for organ transplantation), 3 ) prior to treatment with tumor necrosis factor $\alpha$ (TNF- $\alpha$ ) antagonists, 4) in HIV-infected patients, 5) in the clinical suspicion of tuberculosis [1-3, 7].

Meta-analyses concerning the use of IGRA tests in the diagnosis of $M$. tuberculosis infection in children published in 2010-2012 showed a significantly better IGRA specific- 
ity compared to TT (88\% - QFT-GIT, 90\% - SPOT.TB, $65 \%-\mathrm{TT})$, which was similar to adult population [13, 14]. In turn, the sensitivity of TT is estimated at $70-86 \%$ and IGRA tests at $62-90 \%$. In the course of tuberculosis, the cells of the immune system (primarily T-lymphocytes) from the peripheral blood are transferred to the site of the disease process. In addition, a negative TT may occur due to the processes observed during active disease which involve the stimulation of T-regulatory cells that secrete interleukin 10 which then reduces the inflammatory response [8]. Negative TT results do not exclude latent infection or even active tuberculosis, especially in immunosuppressed patients $[1-3,7,8]$.

According to Lambie [23] $10 \%$ of children with NS may have a concomitant TB infection preceding the onset of TB. However, the exclusion of TB infection in children with NS is not standardized in all children's nephrological centers. There are local recommendations of TT performance to detect LTBI before steroid treatment of INS in children [28]. In our center, children with proteinuria and children with NS have been tested for TB infection with IGRA tests since 2014. Prior to 2014, TT was performed in all children with NS before starting GCS. The detection of TB infection with IGRA carries significant implications for further therapeutic decisions. When LTBI is detected in children with proteinuria/NS, chemoprophylaxis is introduced. In case of active TB, 3 or 4 anti-tuberculous drugs are used in the treatment. The use of GCS $>15 \mathrm{mg} /$ day for 4 weeks and immunosuppressive therapy are factors which increase the risk of both infection with $\mathrm{M}$. tuberculosis and progression to TB disease $[1,5,7,24]$. Therefore, children with NS treated with prednisone at a dose of $60 \mathrm{mg} / \mathrm{m}^{2} /$ day, may be at especially high risk for TB disease. Among our patients, 3 children had been previously treated with GCS because of NS relapses. Each of these patients had a TT prior to the first GCS use (before 2014). All the TTs were negative. The patient with non-nephrotic proteinuria due to mesangial proliferation (case No. 4) had been previously treated only with antiallergic drugs.

According to PTChP recommendations [7], patients treated with prednisone at a dose of $\geq 15 \mathrm{mg}$ per day for more than a month should be tested for TB if there is even a slight evidence of infection or lesions in chest radiography. Apart from proteinuria of varying intensity in all patients, the clinical symptoms that prompted us to perform tests for $M$. tuberculosis infection were: recurrent respiratory symptoms in all the patients and leukopenia in one case and erythrocyturia in one case. None of the patients presented non-specific symptoms such as weight loss, recurrent fever, or sweating. Inflammation indicators were low in all the children. Leukopenia was observed in one case. None of the children had pulmonary abnormalities in radiologic examinations, while in one patient an enlargement of intrathoracic lymph nodes was present in the CT examination. Lymph nodes inside the chest consti- tute the most common extrapulmonary site of tuberculosis in children [1, 27]. All the patients had positive QuantiFERON-TB test results, subsequent examinations of body fluids with bacterioscopy, BACTEC and Gen-Probe test, gave negative results in all 4 children.

Addition of antituberculous treatment to previously used otherapy resulted in remission of NS/proteinuria in all 4 analyzed children.

When tuberculosis infection is detected in a child younger than 5 years of age or primary TB is suspected, it is advisable to look for a person who was the source of infection in high risk areas (school, kindergarten, child's home) [7]. In our group, in case of one boy diagnosed with LTBI, further tests confirmed the diagnosis of LTBI in a cousin attending the same kindergarten suggesting family source of infection. Full family data are in progress. No source of infection was found in the remaining 3 children.

\section{Conclusions}

1. In children with proteinuria/nephrotic syndrome, tuberculosis infection should be considered as one of possible infectious etiopathogenetic factors.

2. In children with NS prior to introducing corticosteroid therapy, and in children with NS refractory to corticosteroid and/or immunosuppressant treatment, it is worth to perform QuantiFERON-TB test.

3. Appropriate antituberculous treatment helps achieve remission in patients with idiopathic nephrotic syndrome and tuberculosis infection.

\section{The authors declare no conflict of interest.}

\section{References}

1. World Health Organization. WHO Global Tuberculosis Report 2016. http://www.who.int/tb/publications/global_report/ en/

2. Erkens CG, Kamphorst M, Abubakar I, et al. (2010): Tuberculosis contact investigation in low prevalence countries: a European consensus. Eur Respir J 36: 925-949.

3. Korzeniewska-Koseła M. Gruźlica w Polsce w 2016 roku. Biuletyn IGiChP.www.igichp.edu.pl/pobierz/Biuletyn_2017.zip

4. Augustynowicz-Kopeć E, Zwolska Z (2008): Epidemiologia gruźlicy u dzieci i niektóre problemy diagnostyki mikrobiologicznej. Post Nauk Med 9: 569-577.

5. World Health Organization Guidelines on the Management of Latent Tuberculosis Infection. Geneva, Switzerland: WHO, 2015.http://www.who.int/tb/publications/latent-tuberculosis-infection/en/

6. Tuberculosis. In: Red Book: 2012 Report of the Committee on Infectious Diseases.Pickering LK, Baker CJ, Kimberlin DW, Long SS (eds.). American Academy of Pediatrics. ElkGroveVillage, IL. 2012: 736-759.

7. Augustynowicz-Kopeć E, Demkow U, Grzelewska-Rzymowska I, et al. (2013): Zalecenia Polskiego Towarzystwa Chorób Płuc dotyczące rozpoznawania, leczenia i zapobie- 
gania gruźlicy u dorosłych i dzieci. Pneumonol Alergol Pol 81: 323-379.

8. Bielecka T, Komorowska-Piotrowska A, Mazur A (2015): Współczesna diagnostyka zakażenia prątkiem gruźlicy u dzieci - czy nadal odczyn tuberkulinowy? Postępy Hig Med. Dosw 69: 1130-1139.

9. Pendzich J, Maksymowicz-Mazur W, Kozielski J (2011): Postępy we współczesnej diagnostyce laboratoryjnej gruźlicy. J Lab Diag 47: 439-446.

10. QuantiFERON®-TB Gold (QFT®) Package Insert. http:// www.quantiferon.com/wp-content/uploads/2017/04/English_ QFT_ELISA_R04_082016.pdf

11. T-SPOT®.TB Package Insert. http://www.tspot.com/wp-content/uploads/2017/07/PI-TB-US-V6.pdf

12. Borkowska D, Zwolska Z, Michałowska-Mitczuk D, et al. (2011): Interferonowy test T-SPOT.TB w diagnostyce latentnego zakażenia prątkiem gruźlicy. Pneumonol Alergol Pol 79: 264-271.

13. 13. Thillai M, Pollock K, Pareek M, et al. (2014): Interferon-gamma release assays for tuberculosis: current and future applications. Expert Rev Respir Med 8: 67-78.

14. 14. Sollai S, Galli L, de Martino M, et al. (2014): Systematic review and meta-analysis on the utility of Interferon-gamma release assays for the diagnosis of Mycobacterium tuberculosis infection in children: a 2013 update. BMC Infect Dis 14 (Suppl.1): S6.

15. Pac M, Bustamante J, Buda P, et al. (2012): Disseminated Mycobacterium tuberculosis complex infection in a girl with partial dominant IFN- $\gamma$ receptor 1 deficiency. Centr Eur J Immunol 37: 378-381.

16. Beck L, Bomback AS, Choi MJ, et al. (2013): KDOQI US Commentary on the 2012 KDIGO Clinical Practice Guideline for Glomerulonephritis. Am J Kidney Dis 62: 403-441.

17. Eddy AA, Symons JM (2003): Nephrotic syndrome in childhood. Lancet 362: 629-639.

18. Kidney Disease: Improving Global Outcomes (KDIGO) Glomerulonephritis Work Group (2012): KDIGO Clinical Practice Guideline for Glomerulonephritis. Kidney int Suppl 2: 139-274.

19. Lombel RM, Gipson DS, Hodson EM (2013): Treatment of steroid-sensitive nephrotic syndrome: new guidelines from KDIGO. Pediatr Nephrol 28: 415-426.

20. Lombel RM, Hodson EM, Gipson DS (2013): Treatment of steroid-resistant nephrotic syndrome in children: new guidelines from KDIGO. Pediatr Nephrol 28: 409-414.

21. Ziółkowska H, Bałasz-Chmielewska I, Grenda R, et al. (2015): Zalecenia Polskiego Towarzystwa Nefrologii Dziecięcej (PTNFD) dotyczące postępowania z dzieckiem z zespołem nerczycowym. Forum Nefrologiczne 8: 238-256.

22. Kemper MJ, Zepf K, Klaassen I, et al. (2005): Changes of lymphocyte populations in pediatric steroid-sensitive nephrotic syndrome are more pronounced in remission than in relapse. Am J Nephrol 25: 132-136.

23. Lambie SH, Cassidy MJ (2003): Minimal change nephropathy and renal tuberculosis. Clin Nephrol 60: 439-440.

24. Kobashi Y, Matsushima T (2002): Clinical analysis of pulmonary tuberculosis in association with corticosteroid therapy. Intern Med 41: 1103-1110.

25. Schwartz GJ, Muńoz A, Schneider MF, et al. (2009): New equations to estimate GFR in children with CKD. J Am Soc Nephrol 20: 629-637.
26. Figueiredo AA, Lucon AM (2008): Urogenital tuberculosis: update and review of 8961 cases from the world literature. Rev Urol 10: 207-217.

27. Mazur A. Gruźlica układu moczowego. In: Gruźlica dziecięca. Ziołkowski J (ed.). Borgis, Warszawa 2010.

28. Gipson DS, Massengil SF, Yao L, et al. (2009): Management of childhood onset nephrotic syndrome. Pediatrics 124: 747757. 